\title{
Pneumocystis carinii pneumonia complicating low dose methotrexate treatment for rheumatoid arthritis
}

\author{
Arie Wollner, Janet Mohle-Boetani, R Elaine Lambert, James L Perruquet, Thomas A \\ Raffin, James L McGuire
}

\begin{abstract}
Low dose methotrexate has been used effectively for various rheumatic and non-rheumatic diseases. Three cases of Pneumocystis carinii pneumonia occurring during treatment of rheumatoid arthritis with low dose methotrexate are presented. Several mechanisms might contribute to impaired immunity and the rare development of opportunist lung infection with methotrexate. A high degree of suspicion may result in earlier diagnosis and treatment.
\end{abstract}

Low dose methotrexate has become an important treatment for rheumatoid and psoriatic arthritis, ${ }^{1}$ and has been recommended for the treatment of severe asthma. ${ }^{2}$ In general, methotrexate treatment is not complicated by opportunist infections. We present three cases of Pneumocystis carinii pneumonia developing during treatment with low dose methotrexate.

\section{Case reports}

PATIENT 1

A 56 year old woman with a five year history of rheumatoid arthritis presented with feeling faint, malaise, and dry cough. She had been treated with ibuprofen $2400 \mathrm{mg}$ /day, prednisone $2.5 \mathrm{mg} /$ day, and oral methotrexate $7.5 \mathrm{mg} /$ week for four years. Physical findings included a temperature of $38.2^{\circ} \mathrm{C}$, a respiratory rate of $32 / \mathrm{min}$, and bilateral basal crackles. The total white blood count was $3.3 \times 10^{9} / 1$ (76\% neutrophils, $15 \%$ band forms, $6 \%$ lymphocytes, and $3 \%$ monocytes). A chest radiograph showed diffuse bilateral interstitial infiltrates and left lower lobe consolidation. Arterial blood gas analysis while she was breathing high concentrations of oxygen showed an oxygen tension of $6.4 \mathrm{kPa}$ and a carbon dioxide tension of $4.7 \mathrm{kPa}$. Grocott-Gomori methenamine silver nitrate staining of bronchoalveolar lavage fluid showed $P$ carinii. The patient recovered after treatment with intubation and ventilatory support for 12 days and trimethoprimsulphamethoxazole $\quad(20 \mathrm{mg} / 100 \mathrm{mg} / \mathrm{kg} /$ day $)$ for three weeks. She had no known risk factors for human immunodeficiency virus infection, and a test for the antibody for the human immunodeficiency virus type 1 (HIV1) by ELISA gave a negative result. She has been treated with ibuprofen and prednisone
$10 \mathrm{mg} /$ day for a further 22 months with no pulmonary symptoms.

\section{PATIENT 2}

A 49 year old woman with a four year history of rheumatoid arthritis had received aspirin $4 \mathrm{~g} /$ day and, for the past nine months, oral methotrexate $7 \cdot 5-15 \mathrm{mg} /$ week. Her blood counts were always normal during treatment. The patient presented with fever after dental extraction. The total white blood count was $1 \cdot 1 \times 10^{9} / 1$. Blood and urine cultures showed no growth and a chest radiograph was normal. She was admitted to hospital for four days and given intravenous penicillin and gentamicin. Three days later she was readmitted with a fever of $39.6^{\circ} \mathrm{C}$, shortness of breath, and diarrhoea. The total white cell count was $3.5 \times 10^{9} / 1 \quad(54 \%$ neutrophils, $1 \%$ band forms, $17 \%$ lymphocytes, $28 \%$ monocytes). A chest radiograph showed increased interstitial markings bilaterally, and a Grocott-Gomori methenamine silver nitrate stain of a transbronchial biopsy specimen showed $P$ carinii. The patient required ventilatory support for nine days. She was treated with trimethoprim-sulphamethoxazole $(20 \mathrm{mg} / 100 \mathrm{mg} / \mathrm{kg}$ a day) and later pentamidine ( $4 \mathrm{mg} / \mathrm{kg}$ a day), and was discharged after three weeks. She denied risk factors for human immunodeficiency virus infection, and the result of a test for antibody to the human immunodeficiency virus type 1 (HIV-1) by ELISA was negative. She has been treated with sulphasalazine, aspirin, and prednisone $5-10 \mathrm{mg} /$ day to control her symptoms of arthritis for 60 months since discharge, with no evidence of lung disease.

\section{PATIENT 3}

A 64 year old woman with a 15 year history of rheumatoid arthritis had been treated for the past 30 months with sulindac $400 \mathrm{mg} /$ day, prednisone $7.0 \mathrm{mg} /$ day, and oral methotrexate $15 \mathrm{mg} /$ week. Her blood count was always normal. She was admitted to hospital with weakness, chills, night sweats, dyspnoea, and cough. Her temperature was $39.4^{\circ} \mathrm{C}$, and lung examination showed bilateral basal crackles. The total white cell count was $2.2 \times 10^{9} / 1$ ( $88 \%$ neutrophils, $2 \%$ band forms, $7 \%$ lymphocytes, $2 \%$ eosinophils, $1 \%$ basophils). The chest radiograph showed diffuse reticulonodular interstitial shadowing. GrocottGomori methenamine silver nitrate staining of bronchoalveolar lavage fluid showed $P$ carinii. Despite ventilatory support and treatment 
Table Characteristics of six patients with arthritis ${ }^{\star}$ who developed Pneumocystis carinii pneumonia during low dose methotrexate treatment

\begin{tabular}{|c|c|c|c|c|c|c|}
\hline \multirow{2}{*}{\multicolumn{2}{|c|}{$\begin{array}{l}\text { Patient Age } \\
\text { No (y) }\end{array}$}} & \multirow[b]{2}{*}{ Sex } & \multicolumn{2}{|c|}{ Methotrexate } & \multirow{2}{*}{$\begin{array}{l}\text { Additional } \\
\text { drugs } \\
\text { (mg/day) }\end{array}$} & \multirow{2}{*}{$\begin{array}{l}\text { White blood } \\
\text { count } \\
\left(\times 10^{9} / l\right)\end{array}$} \\
\hline & & & $\begin{array}{l}\text { Dose } \\
\text { (mg/week) }\end{array}$ & $\begin{array}{l}\text { Duration } \\
\text { (months) }\end{array}$ & & \\
\hline 1 & 56 & $\mathbf{F}$ & $7 \cdot 5$ & 48 & $\begin{array}{l}\text { Prednisone } 2 \cdot 5 \\
\text { Ibuprofen } 2400\end{array}$ & $3 \cdot 3$ \\
\hline 2 & 49 & $\mathbf{F}$ & $7 \cdot 5-15$ & 9 & Aspirin 4000 & $\begin{array}{l}(1 \cdot 1) \\
3 \cdot 5 t\end{array}$ \\
\hline 3 & 64 & $\mathrm{~F}$ & 15 & 30 & $\begin{array}{l}\text { Prednisone } 7 \cdot 0 \\
\text { Sulindac } 400\end{array}$ & $2 \cdot 2 \dagger$ \\
\hline 4 & 74 & $\mathbf{F}$ & 15 & 8 & $\begin{array}{l}\text { Aspirin } \\
\text { Prednisone 5.0 }\end{array}$ & $8 \cdot 2$ \\
\hline 5 & 16 & $M$ & 10 & 10 & $\begin{array}{l}\text { Ibuprofen } 1200 \\
\text { Prednisone } 3.0\end{array}$ & $15 \cdot 1 \dagger$ \\
\hline 6 & 66 & $\mathbf{M}$ & $22 \cdot 5$ & 6 & Tolmetin 1200 & $4 \cdot 2$ \\
\hline
\end{tabular}

$\star$ Psoriatic arthritis in patient 5 and rheumatoid in the rest.

†Transient leucopenia. exposed to low dose methotrexate ${ }^{8}$ may diminish the immune response.

Previous studies have shown considerable variation in methotrexate concentrations in blood after oral and parenteral administration. ${ }^{9}$ Non-steroidal anti-inflammatory drugs raise plasma concentrations of free methotrexate by displacing it from albumin binding sites and by competition for renal secretion. ${ }^{10}$ Thus low dose methotrexate when administered with non-steroidal anti-inflammatory drugs might result in high blood concentrations and immune impairment. Methotrexate concentrations in the lung may be raised ${ }^{11}$ and may thus contribute to local immune derangement and susceptibility of the lung to opportunist infection. The long interval between initiation of methotrexate treatment and pneumocystis pneumonia (table) suggests that the effect of the drug on the immune system may be cumulative.

Reports of opportunist pulmonary infections in patients treated with low dose methotrexate are unusual. ${ }^{134}$ These infections are either rare therefore or underdiagnosed. The experience of Hellmann et $_{\text {al }}{ }^{12}$ with opportunist infections in patients with systemic lupus erythematosus suggests that most infections are not diagnosed before necropsy. ${ }^{12}$ These authors suggested that evaluation of these infections was inadequate, and possibly that this was because the opportunist infection mimicked systemic lupus erythematosus and the investigations did not include specific diagnostic tests. ${ }^{12}$ This observation might also apply to our patients. When a patient with rheumatoid arthritis presents with acute pulmonary disease, drug induced pneumonitis, rheumatoid lung disease, pulmonary emboli, and bacterial infections may be considered before opportunist infections. A higher degree of suspicion for opportunist infection may result in earlier diagnosis and treatment of these conditions.

We present three cases of pneumocystis pneumonia associated with low dose methotrexate and have identified three further cases in published reports. Several possible mechanisms, either alone or in combination, may explain how long term treatment with low dose methotrexate can result in pneumocystis pneumonia. The frequency of this infection must be ascertained as the use of low dose oral methotrexate is increasing to include the treatment of other connective tissue diseases, asthma, and inflammatory bowel disease.

We wish to thank Dr Donald Silcox for providing information about patient 1, Dr Thomas Burns of Kaiser Permanente Medical Center in Santa Clara, California, for providing information about patient 2, and to Patricia Ryan for secretarial assistance. death in one case.

Susceptibility to opportunist infection is usually associated with impaired cellular immunity, but immunological studies of patients treated with low dose methotrexate 5-25 mg/week did not show any change in the number of circulating B lymphocytes, CD4 or CD8 positive lymphocytes, the CD4:CD8 ratio, or mitogen induced proliferation indices. ${ }^{7}$ Alterations in folate mediated amino acid metabolism, however, in lymphocytes

1 Tugwell P, Bennett K, Gent M. Methotrexate in rheumatoid arthritis. Ann Int Med 1987;107:418-9.

2 Mullarky MF, Blumenstein BA, Andrade WP, Bailey GA, Olason I, Wetzel CE. Methotrexate in the treatment of corticosteroid-dependent asthma. N Engl J Med 1988; 318:603-7.

3 Perruquet JL, Harrington TM, David DE. Pneumocystis carinii pneumonia following methotrexate therapy fo rheumatoid arthritis [letter]. Arthr Rheum 1983;26:1291. 4 Wallis PJW, Ryatt KS, Constable TJ. Pneumocystis carini 
pneumonia complicating low dose methotrexate treatment for psoriatic arthropathy. Ann Rheum Dis 1989;48:247-9.

5 Leff RL, Case JP, McKenzie R. Rheumatoid arthritis, methotrexate therapy, and Pneumocystis carinii [letter]. Ann Intern Med 1990;112:716.

6 Wilson WR, Cockerill FR, Rosenow EC. Pulmonary disease in the immunocompromised host. Mayo Clinic Proc 1985;60:610-31.

7 Olsen NJ, Callahan LF, Pincus T. Immunologic studies of rheumatoid arthritis patients treated with methotrexate. rheumatoid arthritis patiens

8 Morgan SL, Baggott JE, Altz-Smith M. Folate status of rheumatoid arthritis patients receiving long-term, lowdose methotrexate therapy. Arthr Rheum 1987;30
1348-56.

9 Noble WC, White PM, Baker H. Assay of therapeutic doses of methotrexate in body fluids of patients with psoriasis. $J$ of methotrexate in body fluids of

10 Groff GD, Shenberger KN, Wilke WS, Taylor TH. Lowdose oral methotrexate in rheumatoid arthritis. An uncontrolled trial and review of the literature. Semin Arthr Rheum 1983;12:333-47.

11 Anderson LL, Collins GJ, Ojima Y, Sullivan RD. A study of the distribution of methotrexate in human tissue and the distribution of methotrexate in

12 Hellmann DB, Petri M, Whiting-O'Keefe Q. Fatal infections in systemic lupus erythematosus: the role of opportunistic organisms. Medicine (Baltimore) 1987;66:341-8. 